\title{
Extremity localized intramuscular hemangiomas, follow up or surgery?
}

\section{Ekstremite yerleşimli intramüsküler hemanjiyomlarda takip mi? cerrahi mi?}

\author{
İsmail Burak Atalay ${ }^{1}$, Yaman Karakoç${ }^{1}$, Selçuk Yılmaz ${ }^{1}$, Murat Arıkan $^{1}$, Emre Özanlağan $^{1}$ \\ ${ }^{1}$ Ankara Onkoloji Eğitim Ve Araştırma Hastanesi, Ortopedi Ve Travmatoloji Kliniği
}

Dergiye Ulaşma Tarihi:29/09/2015 Dergiye Kabul Tarihi:13/10/2015 Doi: 10.5505/aot.2015.84755

\section{ÖZET}

Giriş ve Amaç: $\mathrm{Bu}$ çalışmada ekstremite yerleşimli kas içi hemanjiyom tanılı, takip ve tedavisi yapılmış 44 hastanın geriye dönük analizi incelenmiştir

Yöntem ve Gereçler: Hastaların 25'i kadın, 19'u erkek idi. Hemanjiomların 22'si uylukta, 8'i bacakta, 6'sı önkolda, 4'ü dirsekte, 2'si üst kolda, biri omuzda ve biri popliteal bölgede idi. Malignite şüphesi olan 10 hastaya tru-cut biyopsi yapıldı. Diğer hastalara klinik ve radyolojik olarak tanı konuldu. Hastaların 32'si izleme alınırken, 12'sine cerrahi eksizyon uygulandı.

Bulgular: Hiçbir hastada ameliyat içi istenmeyen durum olmadı. Cerrahi gruptaki 3 hastaya embolizasyon uyguland1. Postoperatif takiplerde 1 hastada enfeksiyon, 2 hastada nüks saptand1.

Tartışma ve Sonuç: Semptomatik ekstremite yerleşimli kas içi hemanjiyomlarda kitlede progresyon olması, ekstremite fonksiyon bozukluğu olması, malignite şüphesi ve giderilemeyen ağrı durumları dışında, izlemin güncel tedavi yöntemi olduğunu düşünmekteyiz.

Anahtar Kelimeler: İntramusküler (kas içi) hemanjiyom, cerrahi.

\begin{abstract}
Introduction: In this study, we evaluated the retrospective analysis of 44 patients with the diagnosis of extremity located intramuscular hemangiomas.

Methods: Twenty five of the patients were female, and nineteen male. Twenty two of the hemangiomas were in thigh, 8 were in cruris, 6 were in forearm, 4 in elbow, 2 in arm, one in shoulder, one in popliteal area. Tru-cut biopsies were performed to ten of them who had malignancy potential. The other patients were diagnosed with clinical and radiological signs. Thirty two patients were followed up. Twelve were treated with total excision. Results: No intra operative complications were recorded. Three patients were treated with embolization, one patient was recorded with local infection, two were recorded with recurrence

Discussion and Conclusion: The current treatment of the symptomatic extremity located intramuscular hemangiomas is conservative follow up, if the patient has not progressive mass, extremity dysfunction, malignancy suspicion or intractable pain.
\end{abstract}

Key words: intramuscular hemangioma, surgery.

\section{Giriş}

Hemanjiomlar hayatın ilk 10 yilının en sik rastlanılan tümörlerinden olup genellikle cilt ve mukozal yüzeylerde izlenirler. İskelet kasından köken alan hemanjiomlar ise nadir görülüp tüm hemanjiomların \%1 inden azını oluştururlar. Hemanjiomların etiyolojisi belli olmayıp Godanich ve Capanacci gibi bazı yazarlar lezyonu hamartom, Mulliken gibi bazı yazarlar ise lezyonu vasküler tümör olarak kabul etmektedir $(1,2)$.

İntramüsküler (kas içi) hemanjiom tanımı ilk kez 1843'te Liston tarafindan yapılmıştır. 1867'de Virschow ilk vertebral hemanjiom vakasını yayınlamıştır (3). Lezyon genellikle genç yaş grubunda görülmekte olup, hastaların \%80-90’1 30 yaş altındadır. Kadınerkek cinsiyette görülme sıklığı eşittir. Sıklıkla alt ekstremitelerde ve özellikle de uylukta ele gelen kitle olarak görülür. Kitle üzerindeki ciltte renk değişikliği bulunmaz. Oldukça nadir görülen intramüsküler hemanjiomlar tüm benign vasküler tümörlerin \%0.8'ini oluşturur.

Hastalar siklıkla yumuşak dokuda kitle, aktiviteyle artan ağrı ve şişlik şikayetiyle başvurur $(2,4,6)$. Tanıda manyetik rezonans incelemeden yararlanilmaktadir. Tedavi lezyonun yerleşim yerine, sınırlarına, hastanın yaşına göre farklılık göstermekte olup, 
tedavide izlem, kortikosteroidler, kriyoterapi uygulamas1, sklerozan ajan enjeksiyonu, arter ligasyonu, embolizasyon ve cerrahi eksizyon seçenekler arasındadır $(5,7)$.

$\mathrm{Bu}$ çalışmada kliniğimizde tanısı konulan 44 intramüsküler hemanjiomlu olguyu retrospektif olarak inceledik.

\section{Gereç ve Yöntem}

Sağlık Bakanlığı Ankara Onkoloji Eğitim ve Araştırma Hastanesi Ortopedi ve Travmatoloji Kliniğinde 2003-2013 tarihleri arasında takip ve tedavisi yapılan 44 ekstremite yerleşimli intramüsküler hemanjiom olgusu klinik özellikleri ve tedavi yaklaşımları yönünden değerlendirilmiştir.

Hastalarımızın 25'i kadın, 19'u erkek olup ortalama yaş 27.3 (3-56) olarak bulundu. Lezyonların yerleşimi 13 olguda üst ekstremite (\%29.5) , 31 olguda alt ekstremite (\%70.5) idi. Üst ekstremite yerleșimli olanların 6's1 önkol, 4'ü dirsek, 1'i omuz, 2'si ise üst kol yerleşimli idi. Alt ekstremite hemanjiomlarının ise 22' si uyluk, 8'i kruris ve 1'i de popliteal bölge yerleşimli idi. Uyluk yerleşimi \%50 görülme sıklığı ile ile en sık görülen bölge idi (Resim 1). Hastaların tamamı ilgili ekstremitede özellikle egzersizle artan ağrı ve şişlik şikâyetiyle geldi. $5 \mathrm{~cm}$ 'den, büyük derin yerleşimli olan olgulara malignite şüphesi ile tru-cut biyopsi yapıldı. Diğer hastalara klinik ve radyolojik yöntemlerle tanı konuldu. Direk grafilerde patolojik bulgu saptanmad. Manyetik rezonans incelemelerde T2 ağırlıklı kesitlerde hiperintens lobüle yapılı heterojen kitle lezyonu saptandi.

\section{Bulgular}

İzleme alınan 32 olgu aktivite kısitlama ve non steroidal anti-inflamatuar tedaviye alınarak 6 aylık periyodlarla kontrole çağrıldı. 12 tanesine geniş cerrahi eksizyon uygulandı. İzleme alınanlardan dirsek yerleşimli olan bir hastaya (Resim 2) dirsek eklem hareketlerinde kisitlılık olması; omuz ve popliteal yerleşimli olan 2 hastaya ise kitlede progresyon olmas1 nedeniyle cerrahi uyguland1. Cerrahi gruptaki 3 hastaya embolizasyon sonrası geniş cerrahi eksizyon yapıldı. Hastaların ortalama takip süresi 52 ay (12-120) idi. Ameliyat sonras1 takiplerde yara yeri enfeksiyonu görülen 1 hastaya debridman ve parenteral antibiyotik tedavisi uyguland.

$$
\text { Cerrahi uygulanan hastaların }
$$
tamamında ağrı şikayetinde gerileme saptandı. Postoperatif dönemde damar-sinir yaralanmasina ait komplikasyon olmadi. Takiplerde uyluk yerleşimli 2 hastaya nüks nedeniyle re-eksizyon uyguland.

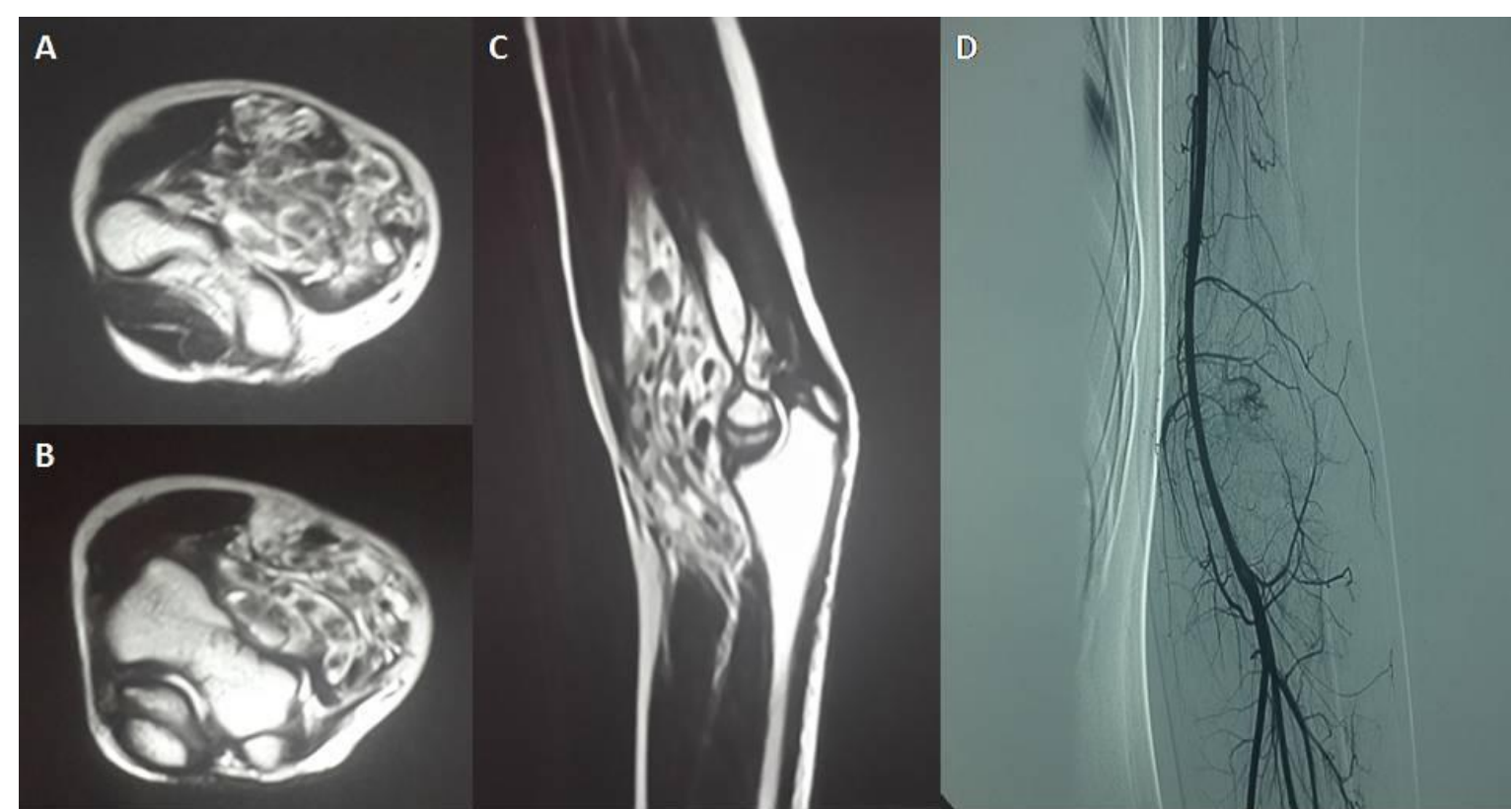

Resim 1: A-B.Aksiyel MR görüntüsünde yüksek sinyalli kıvrımlı alanlar, vasküler kanallardaki yavaş kan akımının göstergesi. C. Sagital mr görüntüsünde kubital bölgedeki sinyal artışı gösteren lezyon D. Ekstremite anjiografide vaskülarizasyon artışı görünümü 

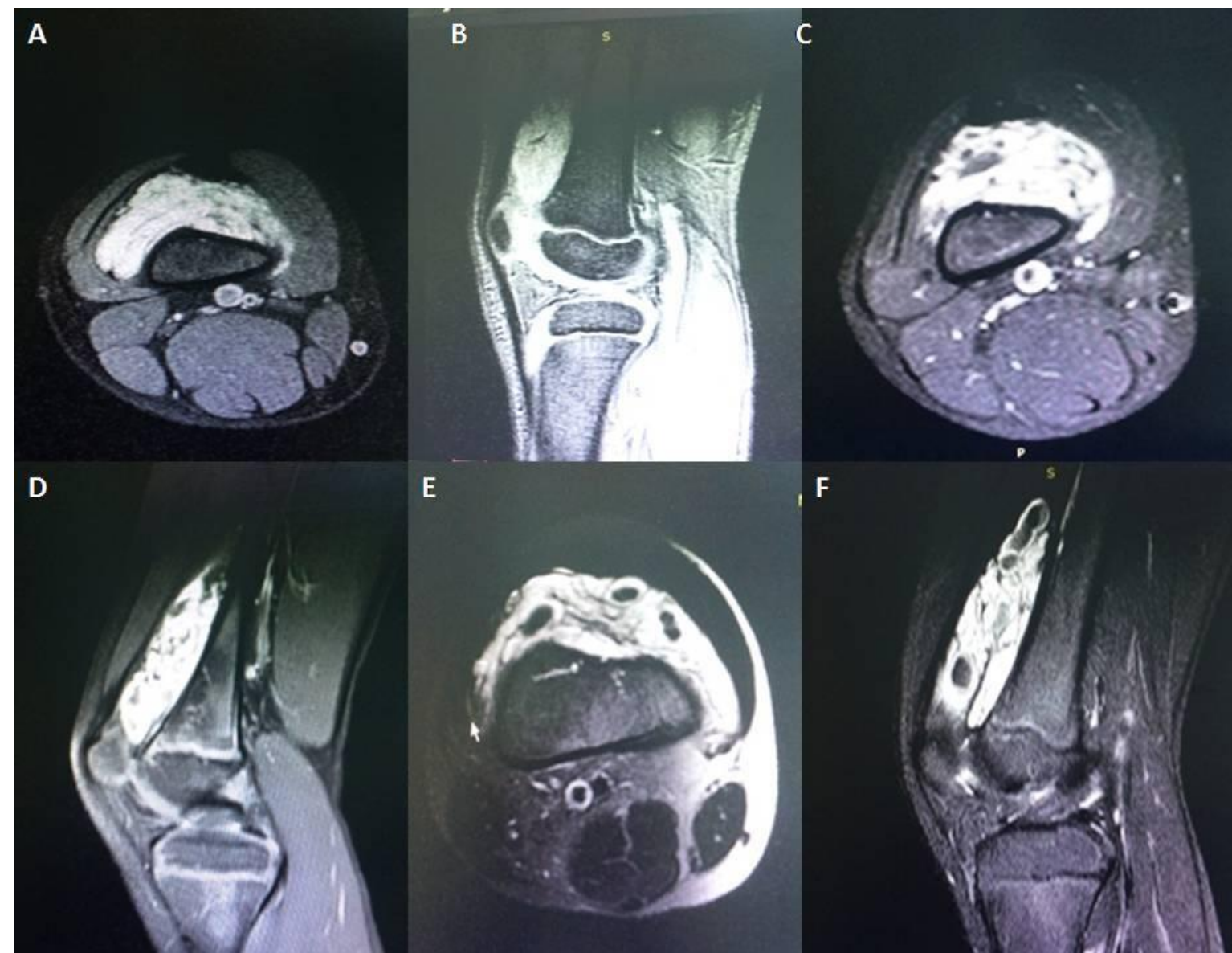

E

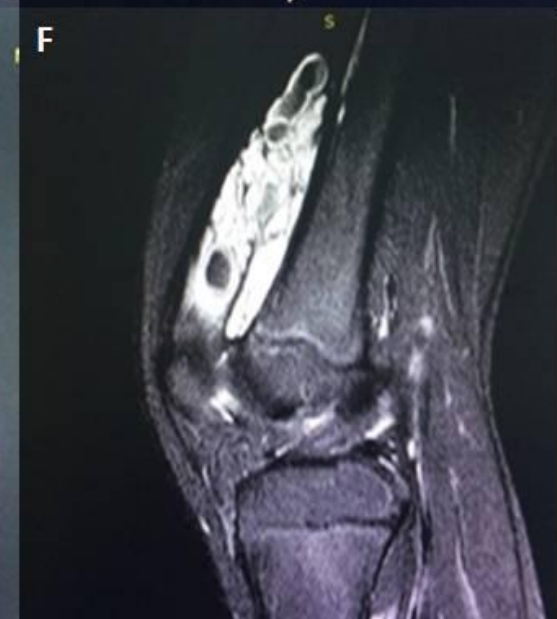

Resim 2: A-B. Uyluk distalde intramuskuler hemanjiom tanısı olan hastanın aksiyel ve sagital mr görüntüleri. C-D. Hastanın 5 yıllık takip sonrası kontrol aksiyel ve sagital mr görüntüleri E-F. Hastanın 10 yıllık takip sonrası kontrol aksiyel ve sagital mr görüntüleri

\section{Tartışma}

Hemanjiomlar en sık görülen yumuşak doku tümörleridir. S1klıkla cilt, cilt altı doku, dalak ve karaciğerde görülürken, kas içinde, ekstremitelerde ve göğüs duvarında nadiren görülür $(1,8)$.

İntramusküler hemanjiom ilk kez 1843'te Liston tarafindan tanımlanmış, Virschow ise 1867 'de ilk vertebral hemanjiom vakasını yayınlamıştır $(6,8)$. Lezyon genellikle genç yaş grubunda görülmekte olup, hastaların \%80-90'1 30 yaş altındadır. Kadın-erkek cinsiyette görülme sıklığı eşittir. S1klıkla alt ekstremitelerde ve özellikle de uylukta ele gelen kitle olarak görülür. Kitle üzerindeki ciltte renk değişikliği bulunmaz. Oldukça nadir görülen intramüsküler hemanjiomlar tüm benign vasküler tümörlerin $\% 0.8$ 'ini oluşturur $(5,9,10)$. Malignleşme potansiyelleri yoktur. Ekstremite ağrısında nadiren akla gelirler. Klinik olarak genelde asemptomatik olabilecekleri gibi yumuşak dokuda ele gelen kitle ve ağr1 ile kendini belli ederler. Kitle üzerinde izole pulsasyon alınabilir. Ekstremite sarkıtıldığında şişlikte artış ve kaldırıldığında ise kitle büyüklüğünde azalma görülebilir. İlgili bölgede kas kontraktürü ve kas güçsüzlüğü gelişebilir (11). Aktivite sonrası artış gösteren kronik ekstremite ağrısı ile yeni ele gelen kitle varlığı intramüsküler hemanjiomlar için tipiktir. Egzersiz sonrası vasküler genişlemeye bağlı hemanjioma doğru kan akımındaki çoğalma ağrıda artışa neden olur $(6,12,13)$.

$$
\text { Tanıda manyetik rezonans }
$$

incelemeden yararlanılmaktadır. Manyetik rezonans incelemede $\mathrm{T} 1$ ve $\mathrm{T} 2$ ağırlıklı kesitlerde yüksek sinyal tutulumlu lobüle alanlar görülür. T2A görüntülerde fibröz dokuyu, hızlı kan akımı olan vasküler yapıları veya fokal kalsifikasyonları temsil eden noktasal veya retiküler tarzda düşük sinyalli alanlar bulunabilir. Direk grafilerde \% 25 oranında kalsifiye flebolitler görülebilir. Bazı kompleks lezyonlarda cerrahi eksizyon veya embolizasyon kararı vermek için anjiyografi faydalı olabilir $(13,14)$. Tedavide izlem, 
sistemik kortikosteroid kullanımı, kriyoterapi uygulaması, sklerozan ajan enjeksiyonu, arter ligasyonu, embolizasyon ve cerrahi eksizyon seçenekler arasındadır $(7,8)$.

Bütün izole intramüsküler hemanjiomlarda konservatif tedavi ve izlem ilk seçenektir. Tümör boyutlarında hızlı artış, tedaviye yanıtsız inatçı ağrı, kozmetik ya da fonksiyonel bozukluk, ani gelişen trombositopeni, ciltte lokal nekroz riski, kitlede malignite şüphesi olması durumunda cerrahi tedavi seçenekleri göz önünde bulundurulabilir.(13,15). Hemanjiomların kompleks ve infiltratif yapisından dolayı cerrahi eksizyon uygulanacak hastalarda çevre normal kas dokusu da cerrahi eksizyon sınırlarına dahil edilmelidir. Yetersiz cerrahi uygulanan olgularda nüks ihtimali yüksek olup, iyi sınırlı, tek kas grubunda yerleşmiş, çevre dokulara minimal invazyon gösteren olgular cerrahi eksizyon açısından uygun olan hastalardır (15). Cerrahi sonrası rekürrens oranı $\% 18$ ile $\% 61$ arasında değişmektedir.

Cerrahi eksizyonun en sik görülen komplikasyonu ise kanamadır $(13,16)$.

Cerrahi dışı tedavi yöntemleri ise yan etkileri ve uzun dönem başarısız sonuçları nedeniyle nadiren tercih edilmektedir. Cerrahi için uygun olmayan hastalarda skleroterapi, radyoterapi, kortikosteroidler ve embolizasyondan yararlanılabilir $(6,13)$. Özellikle çıkarılamayan lezyonlarda embolizasyon ağrı kontrolü yapması, cerrahi esnasında kan kaybını azaltıcı ve postoperatif rekkürens riskini azaltıc1 etkisiyle tercih edilmektedir. Bazı seçilmiş vakalarda çoklu lezyon içi skleroterapi uygulamasında başarılı sonuçlar elde edilmiştir. Kortikosteroid kullanımı ve radyoterapi ise primer olarak sistemik hastallklarda tercih edilmekte olup intramüsküler hemanjiomlarda nadiren kullanılmaktadır( 11,16$)$.

Sonuç olarak ekstremite yerleşimli intramüsküler hemanjiomlar nadir görülen tümörler olması ve genellikle asemptomatik olmaları nedeniyle sik akla gelmeyen lezyonlardır. Tedavilerinde eğer kitle küçük ve asemptomatik ise, kozmetik bozukluğa neden olmuyorsa, medikal tedaviyle hastanın ağrıları giderilebiliyorsa ilk tedavi yöntemi izlemdir. Konservatif tedaviye rağmen kitle boyutlarında artış, inatçı ağrı, ilgili ekstremitede fonksiyonel bozukluk ya da malignite şüphesi varlığı cerrahi tedavi uygulamayı düşündürmelidir.
Manyetik rezonans inceleme yüksek oranda tanı koydurucu olsa da kesin tanı için şüpheli lezyonlarda tru-cut biyopsi uygulamas gerekir. Çıkartılamayacak kadar büyük lezyonlarda hem cerrahi sırasında kanamayı azaltmak hem de kitle boyutlarını küçültmek amacıyla embolizasyondan faydalanılabilir. Eğer yapılacaksa cerrahi eksizyon yüksek nüks oranları nedeniyle geniş olarak ve çevre normal dokuları da içerecek şekilde uygulanmalıdır.

\section{Çıkar Çatışması: Yok}

\section{Kaynaklar}

1. Tang P, Hornicek FJ, MD, Gebhardt MC, Surgicaltreatment of hemangiomas of soft tissue. Clin.Orthop. 2002; 399:205-10

2. Klemme WR, James P, Skinner SR. Latent onset unilateral toe-walking secondary to hemangioma of the gastrocnemius. J Pediatr Orthop 1994; 14:77375

3. Mulliken JB. Cutaneous vascular anomalies. Plastic Surgery: Tumors of the Head \& Neck and Skin. Philadelphia:. WB Saunders Co. 1990:3191-223

4. Watson WL, McCarthy WD. Blood and lymph vessel tumors. A report of 1056 cases. Surg Gynecol Obstet. 1940;71:569-88

5. Domb BG, Khanna AJ, Mitchell SE, Frassica FJ. Toe-walking attributable to venous malformation of the calf muscle. Clin Orthop 2004;420:225-29

6. Brown RA, Crichton K, Malouf GM. Intramuscular haemangima of the thigh in a basketball player. Br.J. Sports Med. 2004;38:346-48

7. Sutherland $\mathrm{AD}$. Equinus deformity due to haemangioma of calf muscle. J Bone Joint Surg. 1975 ;57B:104-05

8. Murat G, Sami S, Yavuz K, Fevziye K, Ufuk Ö. Ekinizmin sik rastlanmayan etyolojisi: Intramusküler hemanjiom Ş.E.E.A.H. Tıp Bülteni 2011;45(1):30-34

9. Weiss SW, Goldblum JR. Benign tumors and tumor-like lesions of blood vessels ed. Enzinger and Weiss's Soft Tissue Tumors, 4th ed. St Louis: CV Mosby, 2001; 837-90

10. Campanacci M. Angiomas and angiodysplasias. In bone and Soft Tissue Tumors, 2nd ed. Springer Verlag. Wien New York, 1999;1051-77

11. Wild AT, Raab P, Krauspe R. Hemangioma of skeletal muscle. Arch Orthop Trauma Surg. 2000;120(3-4):139-43

12. Olsen KI, Stacy GS, Montag A. Soft-tissue cavernous hemangioma. Radiographics. 2004 MayJun;24(3):849-54

13. Joseph M, Jeffrey H, Mark T, MD, Charles H, John D, James R, Intramuscular Hemangiomas Sports Health. 2013;Sep 5(5): 448-54

14. Buetow PC, Kransdorf MJ, Moser RP, Jelinek JS, Berrey BH. Radiologic appearance of intramuscular hemangioma with emphasis on MR imaging. AJR. 1990;154:563-67 
15. Bella G, Manivel J, Thompson R, Clohisy D, Cheng E. Intramuscular hemangioma: recurrence risk related to surgical margins. Clin Orthop Relat Res. 2007;459:186-91
16. Tang P, Hornicek FJ, Gebhardt MC, Cates J, Mankin HJ. Surgical treatment of hemangiomas of soft tissue. Clin Orthop Relat Res. 2002;399:205-10 